\title{
Analysis of Humanistic Concern in Students’ Ideological and Political Education of Higher Vocational Colleges
}

\author{
Na Wang ${ }^{1}$ \\ ${ }^{1}$ Shaanxi Vocational College of National Defense Industry, Xi'an, Shaanxi Province, 710300
}

Keywords: Humanistic Concern, Students’ Ideological and Political Education, Higher Vocational Colleges

\begin{abstract}
The progress and development of the times call for an internal review of the ideological and political education of college students from the perspective of humanistic care, and fully recognize the necessity and importance of cultivating ideological and political education for college students with humanistic care. In the ideological and political education of college students with humane care, we must insist on the guidance of Marxism as a theory. At present, it is essential to actively explore and construct a security system that achieves humanistic care for college students' ideological and political education in order to improve the pertinence and effectiveness of ideological and political education for college students.
\end{abstract}

\section{Introduction}

The report of the 17th National Congress of the Communist Party of China put forward for the first time "Strengthening and improving ideological and political work, paying attention to humanistic care and psychological counseling." In the field of ideological and political work, humanistic care refers to the respect for the subject's status and individual differences. He cares for the rich and diverse individual needs, inspires people's initiative, enthusiasm and creativity, and promotes the free and full development of people. However, the reality of humanistic concerns in ideological and political education is difficult to embody, which leads to the lack of effectiveness of ideological and political education. Especially in higher vocational colleges, how to combine the characteristics of higher vocational students, integrate more humanistic concerns in ideological and political education, and construct ideological and political education that conforms to the laws of ideological and political education and is consistent with the spirit of the times and the overall development of people. The theoretical system to improve the effectiveness of ideological and political education is undoubtedly of great theoretical and practical significance.

\section{Persisting in Humanistic Care: The Inevitable Choice of Ideological and Political Education in Higher Vocational Colleges}

First, humanistic care is the fundamental requirement of ideological and political education in higher vocational colleges. The core of ideological and political education is people. Its fundamental goal is to liberate people and develop people. Undergraduates' ideological and political education pays attention to humanistic care. Its fundamental purpose is to be student-centered. It embodies the concern for students' survival and development, and emphasizes respect, care, concern and respect for students. Students in higher vocational colleges lack the motivation to study, lack self-confidence, and have a low self-esteem mentality. They have a poor understanding of organizational discipline, poor self-discipline, indulging in online culture, immature ideological and political ideas, and diversified values. It is precisely because of these characteristics of vocational students that the ideological and political education must implement humanistic care. Higher vocational colleges are the last batch of enrollment. Many people think of higher vocational colleges as the focus of poor students. This virtually eliminates the exclusion of candidates from vocational colleges. The upper vocational colleges are considered by students to be a college entrance exam failure. Of course, the final choice of vocational schools for students is mainly due to 
the disadvantages of their own performance. They are subject to the frustrations of the college entrance examination, the pressure of social families, and the scars of the soul. Some students are admitted to vocational schools without any sense of accomplishment [1]. Therefore, the ideological and political education in higher vocational colleges is faced with a highly psychological object of education and the work is more difficult. For students of different abilities, only humane care is implemented, students are taught in accordance with their aptitude, and their potential is fully tapped to stimulate their enthusiasm for learning. Under the prevailing weak cultural foundation, they learn to use their own strengths and adapt to society. Really achieve the effectiveness of ideological and political education. In the ideological and political education of higher vocational students, it is necessary to strengthen humane care, respect and understand students in higher vocational colleges, and care for and motivate students in higher vocational colleges, and to develop and improve higher vocational students. This is the fundamental requirement for ideological and political education for higher vocational students.

Secondly, humanistic care is the innovative starting point for ideological and political education of higher vocational students. The special nature of higher vocational education determines the differences in the ideological and political education among students in higher vocational colleges and ordinary colleges and universities. Higher vocational education is a higher education aiming at cultivating applied and compounded talents. It is different from skilled secondary vocational education and research-based general higher education. Occupation is the biggest feature of higher vocational education. The ideological and political work of higher vocational colleges should firmly grasp the distinctive feature of occupationalism. This is the premise for us to explore the ideological and political work of higher vocational colleges [2]. The skill of higher vocational education training target determines the relationship between professional knowledge education and ideological and political education. People often only pay attention to the cultivation of vocational skills while ignoring the education of ideological and moral theories. The ideological and political education for higher vocational students is a powerful driving force. From ideological understanding to education in ideals and beliefs, moral personality, and ethical norms, attention must be paid to humane care. We take the survival, development, security and self-esteem of vocational college students as the starting point and destination, and respecting, understanding and promoting the overall development of vocational college students as the value scale, maintaining the main position of higher vocational students to meet the individual needs of higher vocational students. . Only in this way can the affinity and appeal of higher vocational students' ideological and political education be enhanced, their potential be maximized, their subjective initiative stimulated, and the students of higher vocational colleges grow with confidence, health, and happiness. The new content, new methods and new forms that the vocational students are happy to accept form a synergy between education and self-education, which transforms the ideological and political education of higher vocational students into a firm belief that externalization is a noble act. In short, the correct search for the basis of humanistic care in ideological and political education for higher vocational students is an important innovation in improving the effectiveness of higher vocational education for ideological and political education.

Third, humanistic care is a practical requirement for the comprehensive development of higher vocational students themselves. In order to achieve full-scale development in the true sense, college students must not only master the knowledge and skills needed for social development, but also need to enrich and improve their spiritual world, possess a noble moral quality and sentiment. At present, higher vocational colleges have a tendency to attach importance to the cultivation of vocational skills and scientific and cultural knowledge of undergraduates and relatively neglect the ideological and political quality education of undergraduates. For a long time, the lack of effective humanities education has led to a poor student's cultural quality and level of ideological understanding. Low, this makes the development of college students' ideas and behaviors lag behind the development of their knowledge capabilities, and the overall quality is not fully developed. If the ideological and political education of higher vocational college students really wants to improve the quality of higher vocational college students, we must put the ideological and political education 
in higher vocational schools into the perspective of humanistic concern, persist in the scientific development concept, take students as the basis, and give full consideration to the psychological characteristics and behavior of higher vocational students. Characteristics, so as to enhance the subjective awareness of higher vocational students, mobilize their enthusiasm for learning and initiative to the maximum extent, so that they consciously and proactively understand themselves and improve themselves, and shape themselves into social entities with outstanding personality characteristics and good qualities. This can effectively face life, adapt to society, and realize your own life value. Humane care is in line with human nature and is an all-round comprehensive educational activity of educating people, nurturing the mind, and educating people. It is a kind of communication between people's and human minds, a spiritual fit, and a mutual understanding of human subjects. Exchange activities. It includes the teaching of knowledge content, understanding of the connotation of life, and the norms of will-being behavior. At the same time, it teaches the younger generation to the younger generation through the function of cultural transmission and enables it to actively recognize itself, seek truth, and improve its personality. Shaping has become a social subject with excellent personality characteristics and good quality, and finally meets the realistic needs of the overall development of college students [3].

\section{The Measures to Enhance the Effectiveness of Humanistic Care in Ideological and Political Education in Higher Vocational Colleges}

Actively change the concept of ideological and political education, and enhance the understanding of humanistic care to enhance the effectiveness of humanistic care in ideological and political education in higher vocational colleges, we must first correctly understand the importance and role of humanistic care in ideological and political education for college students. This requires the party and the government as well as Ideological and political education theoretical circles and the joint efforts of college students' ideological and political educators. The party and the government must further formulate policy provisions on the existing requirements for humanistic care, and further highlight the important role of humanistic care; theorists must deepen scientific research and discussion on humanistic concerns in ideological and political education in higher vocational colleges. Systematic and complete scientific theory can better guide the practice of humanistic care in ideological and political education, and enhance vocational colleges and educators' overall understanding of humanistic concerns in ideological and political education of college students, so as to improve the effectiveness of humanistic care implementation; We must actively adopt various measures to improve the consciousness and initiative of the ideological and political educators in learning relevant theories of humanistic care in the ideological and political education of university students; educators must actively integrate education management practices, actively update educational concepts, and constantly open up new ideas for humanistic care. New horizons must understand the actual situation of college students and the level of various needs, and should not be limited to a certain part. Only in this way can the humanistic concerns in ideological and political education be targeted. The ideological and political education work process is actually the initiative of educators to educate them. Inculcators educate the educators and instructive The two-way interactive acceptance of educational content is selected and absorbed. The need for care can ensure the vitality of ideological and political work [4].

Creating a strong ideological and political education in higher vocational colleges humanistic ideological and political education is implemented in a certain social environment. People's ideological and moral qualities are always formed in a certain social environment. A good social environment is for people. The formation of ideological and moral qualities has a catalytic effect. A good social environment is also an invisible appealing force. It has the effect of infection and subtle influence. It plays a guiding and normative role, can guide the behavior of individuals, and promotes the improvement of ideological and moral qualities. This requires that the whole society must pay attention to ideological and political education, integrate the forces of the entire society, strive to create a good human environment, improve people's ideological and political qualities, and promote the overall development of people. To establish a good humanistic environment for 
ideological and political education, the first is to establish a human-oriented institutional environment that conforms to human nature. At present, many student management systems in higher vocational colleges lack humanistic thinking, and student management is still an administrative order in the pyramid management system.

Improve the humanistic care quality of ideological and political educators in higher vocational colleges. The ideological and political educators' humane care literacy is the fundamental influencing factor for the ideological and political educators of colleges and universities to play a leading role in education and management. At present, the ideological and political education workers in many vocational colleges are unstable, their structures are irrational, and they are lacking. Due to lack of professionalism and lack of humane care spirit, the effectiveness of ideological and political education is weakened. Therefore, the ideological and political educators of higher vocational colleges must be improved in their humanistic literacy. First, we must establish a people-centered education philosophy, and in the positioning of education goals, we must Guide educators to caring for students' growth, caring for students' needs, caring for students' individual development and moral enhancement, and taking students' all-round development as their ultimate goal, promoting ideological and political education to cultivate, shape, develop, and enhance people's value; in educational content In the past, let ideological and political education be closer to students and close to students' lives. Think of students' needs, thoughts, and hopes as starting points and starting points for ideological and political education, focusing on learning, talent, life, friends, love, and job hunting. Targeted ideological and political education on issues such as employment; To respect the personality of college students, to care for their lives, to understand their ideas, to adhere to the reality, to live close to students, to achieve from the emphasis on theoretical indoctrination to focus on infiltration and expansion, through ideological guidance, behavior guidance and value guidance to promote students in thinking, The benign changes in behavior and value selection must be achieved in the education process. Students should be ideologically molded, nurtured, developed, and promoted in the practice of social life. They should pay attention to the vital interests of students and safeguard their legitimate rights and interests. Second, establish the concept of equality education and establish an interactive, teacher-student relationship of equality, trust, and sincerity. Educators must fully respect the equal status of college students in respect of ideological and political education, respect their personality and personality, and treat each student equally as well. Listen to students' opinions and conduct equal teacher-student dialogues and exchanges. Thirdly, to improve the ability of spiritual care, the ideological and political educators of college students must first cultivate the ability to understand and accept in practice, place themselves in the fresh living and learning environment of college students, and take root in the learning and life situations of students and experience their meanings. They are actively creating opportunities for students to gain freedom and relaxation of their thoughts, so that they feel comprehended and accepted, and they must consciously cultivate the ability to communicate emotionally in their work, be sensitive to feelings, be good at expressing, and convince students that they are Recognize that the educational information received meets its own needs and generates psychological resonance [5].

\section{Conclusion}

Schools are the main positions of ideological and political education. It is necessary to first create a harmonious education environment, including: setting up reasonable humanities courses and carrying out rich humanistic practice activities so that the school's school spirit, teaching style, study style, campus culture, and interpersonal relationships Relations, service management, and hardware devices are all full of humanities. In addition, families, work units, and society are also important sites for ideological and political education. It is also necessary to inject factors of humanistic care. 


\section{References}

[1] Liu Yuping. Research on the Humanistic Concern for Ideological and Political Education in Higher Vocational Colleges[J]. Journal of Henan Radio \& TV University, 2010, (1): 69- 71.

[2] $\mathrm{Hu} \mathrm{X}$, Cui SQ. Construction of humanistic care mechanism in ideological and political education for higher vocational students [J]. Pragmatism, 2009, (2): 159- 162.

[3] Gao Yanqing. Humanistic care: The core values of ideological and political education in colleges and universities [J]. Journal of National Academy of Education Administration, 2009, (4): 56- 60.

[4] Chen Bo. Study on Humanistic Concern of College Students' Ideological and Political Education [D]. Southwest University, 2009:17- 30

[5] Qiu Weiguang, Zhang Yaocan. Principles of Ideological and Political Education [M]. Beijing: Higher Education Press, 1999: 145-146. 